Vietnam Journal of Earth Sciences 36 (2014) 403-412

Vietnam Academy of Science and Technology
Vietnam Journal of Earth Sciences
Website: http://www.vjs.ac.vn/index.php/jse

\title{
Geochemistry of Neogene Basalts in the Nghia Dan district, western Nghe An
}

\author{
Nguyen Hoang $*^{1}$, Masatsugu Ogasawara ${ }^{2}$, Tran Thi Huong ${ }^{1}$, Phan Van Hung ${ }^{1}$, Nguyen Thi Thu ${ }^{1}$, \\ Cu Sy Thang ${ }^{1}$, Pham Thanh Dang ${ }^{1}$, Pham Tich Xuan ${ }^{1}$ \\ ${ }^{1}$ Institute of Geological Sciences, Vietnam Academy of Science and Technology, Hanoi, Vietnam \\ ${ }^{2}$ Geological Survey of Japan, AIST, Higashi 1-1-1, Tsukuba Central $7^{\text {th }}$, Tsukuba, Japan 305-8567
}

Accepted 09 December 2014

\section{ABSTRACT}

Nghia Dan Neogene basalts occur as monogenetic volcanoes and thin lava layers (up to tens of meters thick). They are alkaline basalts and basanites, some containing mantle xenoliths such as spinel lherzolite. Compared with Tay Nguyen (Western Highlands) Cenozoic basalts (for example, Pleiku and DacNong) the Nghia Dan basalts show much lower $\mathrm{SiO}_{2}(45-48.5 \mathrm{wt} . \%$ ) and higher $\mathrm{FeO}^{*}$ (up to 9-11 wt.\%), $\mathrm{TiO}_{2}$ (2.5-3 wt.\%) and $\mathrm{CaO}$ (9-10 wt.\%); they are very high in trace element contents especially $\mathrm{Ba}, \mathrm{Th}, \mathrm{Nb}$ (up to $130 \mathrm{ppm}$ ), $\mathrm{Sr}$ (up to $2000 \mathrm{ppm}$ ) and $\mathrm{Eu}$ (up to $4 \mathrm{ppm}$ ). Their rare earth concentrations are high, much higher as compared to those of Tay Nguyen. Melting parameter modeling shows the Nghia Dan melts generated from about $3-4 \%$ partial melting of a combined garnet- spinel- lherzolite source between a pressure range of 20 to $25 \mathrm{~Kb}$ (about $75 \mathrm{~km}$ deep). The parameters are consistent with the low $\mathrm{SiO}_{2}$ and high trace element, including the rare earth, contents in the Nghia Dan basalts. $\mathrm{High}_{\mathrm{FeO}}$, $\mathrm{TiO}_{2}$, $\mathrm{CaO}$ and $\mathrm{Sr}$ may also be a result of interaction with mafic components in the lithospheric mantle by the mantle-derived melts on the way to the surface.

Keywords: Nghia Dan, Neogene basalt, monogenetic volcano, mantle xenolith, geochemistry, partial melting

(C) 2014 Vietnam Academy of Science and Technology

\section{Introduction}

Neogene basaltic occurrence in the Nghia Dan district (western Nghe An province) and the nearby Nhu Xuan district (Thanh Hoa province) is part of Neogene volcanic activities that occurred in many localities in Viet Nam, especially, in the central Highlands (N.K. Quoc and N.T. Giao, 1980; Rangin et al., 1995; Hoang and Flower, 1998; Hoang et al., 1996, 2013), East Sea (South China Sea, Tu et al., 1991) following the cessation of East Viet Nam Sea (EVS) opening as a consequence of the India-Eurasian collision about 40 m.yrs ago (Flower et al., 1998, after Tapponnier et al., 1982, 1986).

*Corresponding author, Email: hoang_geol@hotmail.com
Similar to the Highland basalts, Nghia Dan and Nhu Xuan (hereafter Nghia Dan) basalts occur at intersections of regional fault systems (Fig. 1). The Nghia Dan volcanic plateau comprises a number of monogenetic volcanoes, forming a lava cover with thickness ranging from several meters to more than $200 \mathrm{~m}$. The volcanoes include Nui Tien (Nghia Son village), Nui Hang (Nghia Lam), Doi Tro and Doi Troc (Nghia My) and Nui Ro (Xuan Binh). The basalts are both massive and porous, but porous lava type is dominant. The massive type sometimes occurs as 4-to-5 sided columnar lavas (KeLui, Nghia Lam) (Figs. 2ab). Information on Nghia Dan basalt is poor. A local geological map at 1:50,000 and 1:200,000 (Vinh Sheet, Geological Map of Viet Nam) assume age of the basalt is 
Nguyen Hoang et al./Vietnam Journal of Earth Sciences 36 (2014)

$\mathrm{Q}_{\text {II-III }}$ (Pliocene-Pleistocene, <5.3 m.yrs). An Ar-Ar age of 5.9 Ma (C.T. Chi et al., 1998) for a sample collected in the Nghia My village area; and another was dated to $4.2 \mathrm{Ma}$ (Lee et al., 1998). Some weathering products from porous basalts can be used as additives in cement industry, therefore, to date, research of Nghia Dan basalts is primarily serving the local cement industry.

We had conducted three survey and sampling trips to Nghia Dan. Samples included fresh basalts and mantle xenoliths (wherever available) at localities in the Nghia Dan and Nhu Xuan districts (Fig. 1). The samples were processed for petrographic study, and were analyzed for geochemical and $\mathrm{Sr}-\mathrm{Nd}-\mathrm{Pb}$ isotopic compositions. The data were interpreted for mantle source and parameters of the basaltic melt generation. The data were compared with representatives of the Highland Neogene - Quaternary basalts to study the similarity or difference in the geochemistry of mantle sources and regional geodynamics. This is our first of two reports on the Nghia Dan volcanism.

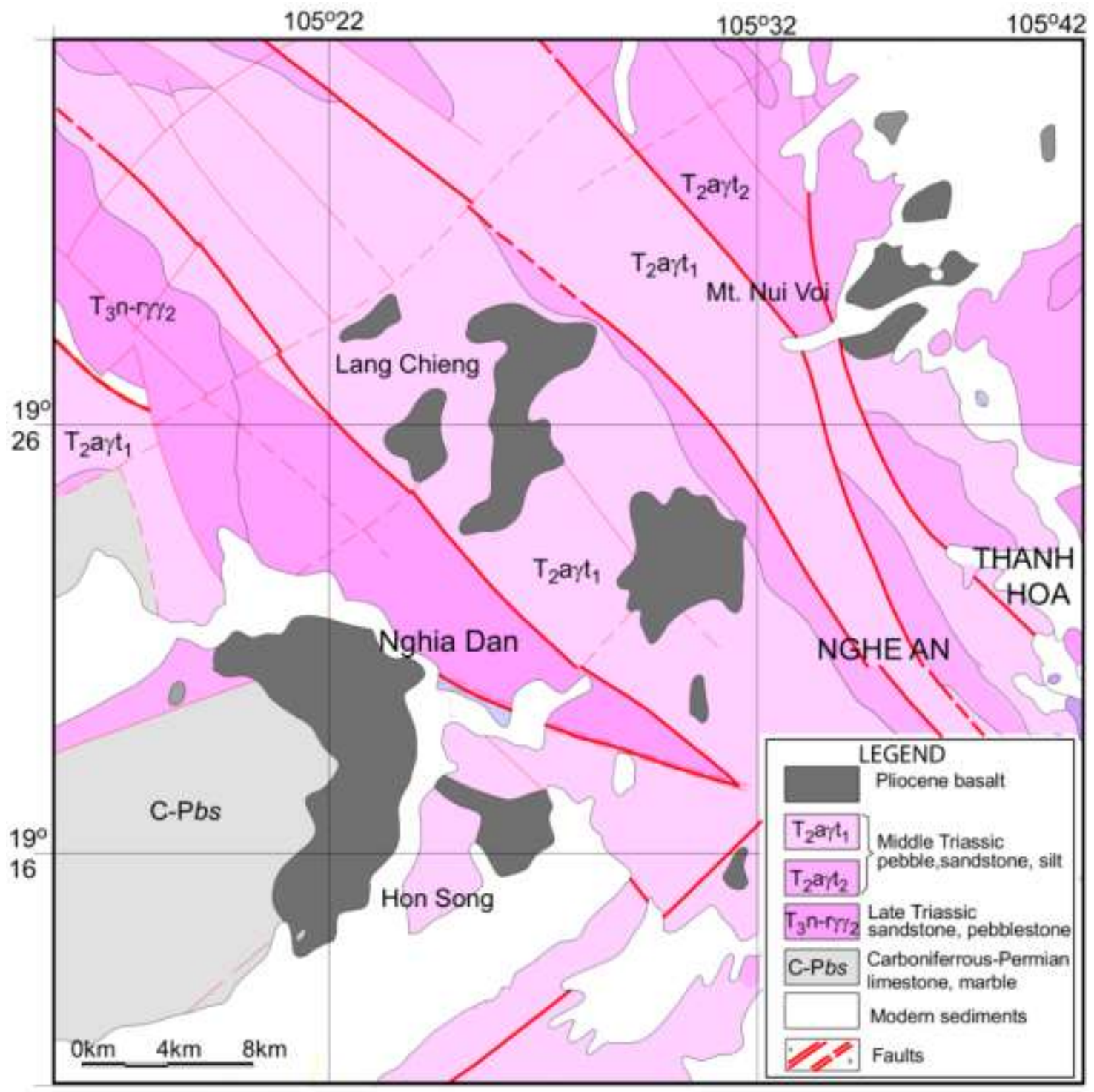

Fig. 1. Distribution scheme of Neogene basalts in the Nghia Dan (Nghe An province) and Nhu Xuan (Thanh Hoa province) districts; simplified from 1:200,000 Geological Map of Vietnam 
Vietnam Journal of Earth Sciences 36 (2014) 403-412

\section{Sampling and analytical procedures}

Basalt and mantle xenolith sampling was conducted at volcanoes in the areas of Nghia Son, Nghia Lam, Nghia My (Nghia Dan district) and Nhu Xuan (Nhu Xuan district) villages (Figs. 2a, b). The samples are fresh and massive basalt, as porous lavas are almost weathered.

Thin sections were made for microscopic study (Figs. 3a and b) and selection for geochemical analysis. The basalts are mostly phyric with

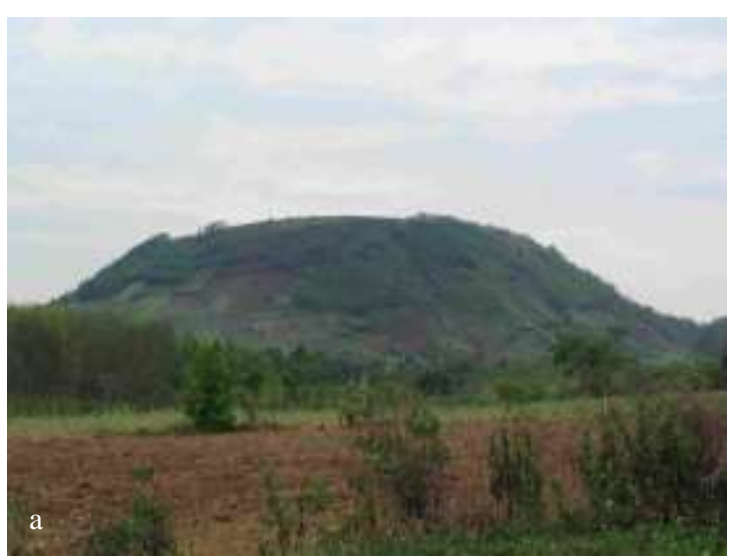

olivine, sized from 0.5 by $1 \mathrm{~mm}$ to $1 \mathrm{~mm}$ by $2 \mathrm{~mm}$, being the major phenocryst phase, having from 5 to 12 vol.\%. The groundmass is intersertal, intergranular, or micro-doleritic, containing microlites of pyroxene, plagioclase and a minor amount of olivine. Ore minerals such as magnetite and ilmenite and volcanic glass are commonly present in the groundmass. The compositions of olivine phenocrysts determined by EPMA (electron probe micro-analysis) range between $\mathrm{Fo}_{67}$ and $\mathrm{Fo}_{73}$.

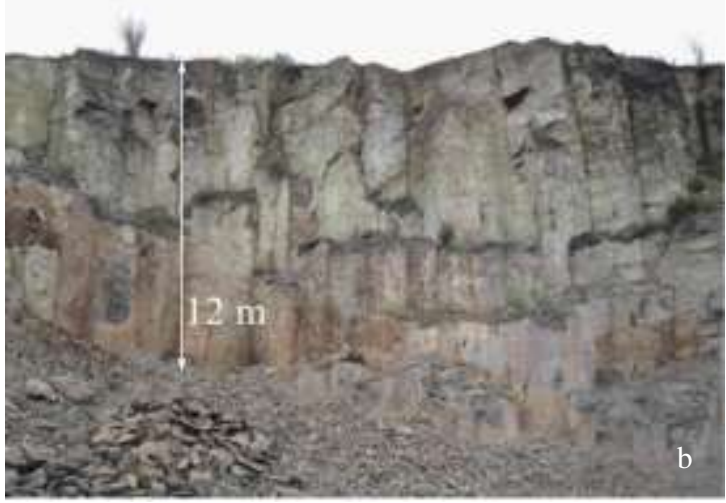

Fig. 2. a- A monogenetic volcano characterized for volcanic activity in Nghia Dan. The weathering layer is up to $5 \mathrm{~m}$ thick serving as a fertile soil cover for local agricultural use; b-An alkaline basalt outcrop at Nui Hang (Nghia Lam village). The basalt is massive, 4 to 5 -sided columnar, rarely fractured (sample 040313-12)

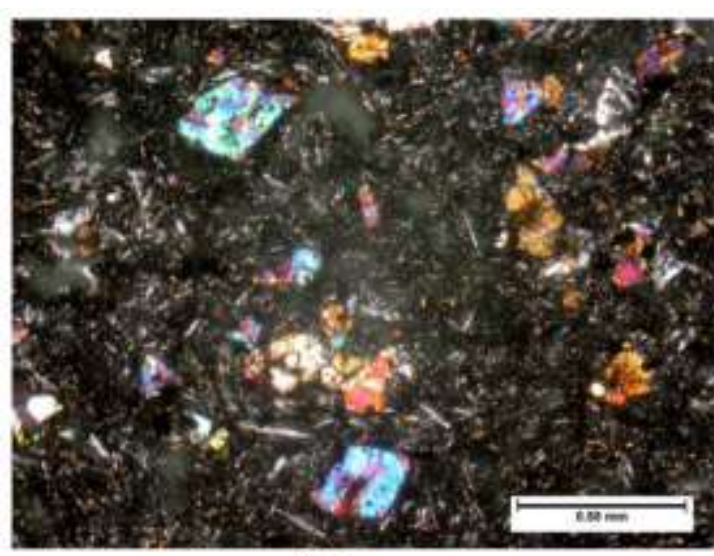

(a)

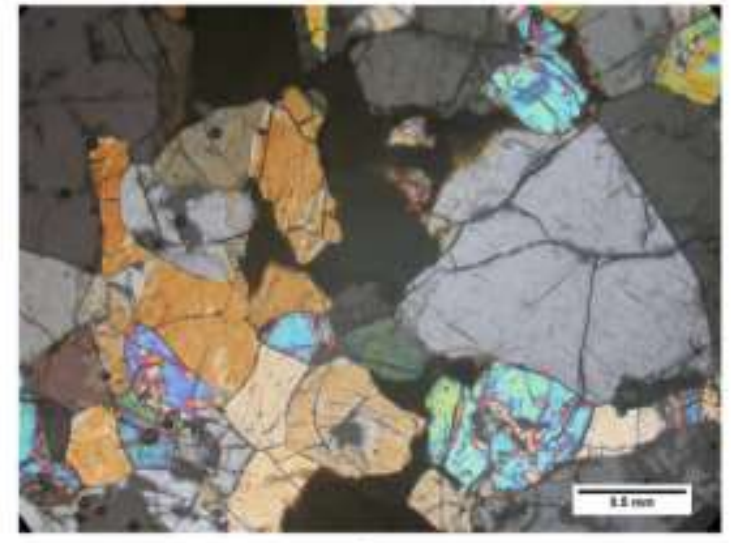

(b)

Fig. 3. A-An porphyric alkaline basalt (sample 040213-16C), Doi Tro, Nghia My village (Nghia Dan) showing idiomorphic olivine phenocrysts with sizes ranging $0.1 \mathrm{~mm}$ to $1 \mathrm{~mm}$ long. The groundmass is intersertal containingmicrolites of needle-shaped plagioclase intercalated with clinopyroxene. Nichol (+); the ruler is $0.5 \mathrm{~mm}$; b-Alkaline basalt-bearing xenoliths of spinel -lherzolite found at Ke Lui, Nghia Lam village (Nghia Dan). The rock-forming mineral compositions are olivine (85 vol.\%), orthopyroxene (10 vol.\%), clinopyroxene (ca. 5 vol.\%) and spinel (<1 vol.\%) distributing between or within olivine crystals; Nichol (+)

Basalt-borne mantle xenoliths are discovered at several volcanoes in Nghia My and Nghia Son villages. The xenoliths are spinel-lherzolites having sizes ranging from $<1 \mathrm{~cm}^{3}$ to $5 \times 10 \times 10 \mathrm{~cm}$. The 
Nguyen Hoang et al./Vietnam Journal of Earth Sciences 36 (2014)

mantle xenoliths' rockforming minerals include lemon-yellow olivine ( 75 - 85 vol.\%), glassy-dark orthopyroxene(Opx) (15 - 20 vol.\%), dark green clinopyroxene (Cpx) (3 - 7 vol.\%) and reddish-brown spinel (Sp) $(<2$ vol.\%) (Fig. 3b). A spinel-lherzolite collected at a volcano in Nghia Son village shows the following mineral compositions, olivine Fo =90.2; Cpx: Fs $=5,4$ En = 57,6 Wo = 39,2; Opx: Fs = $9,7 \mathrm{En}=89,5 \mathrm{Wo}=0,9$; and chromium index $(\mathrm{Cr} \#)$ in the spinel is 6.3. Compared with a spinel-lherzolite xenolith in alkaline basalts in Ia Bang village (Pleiku) the magnesian indexes in all above minerals are much higher and $\mathrm{CaO}$ is lower ( $\mathrm{N}$. Hoang, unpublished data).

For the analysis, Geological Survey of Japan (GSJ)'s 12 geo-standards were used for the calibration and the accuracyevaluation. Basing on the repeated measurements of JB-1a, an GSJ basalt standard, accuracy of the major elements is better than \pm $0.5 w t \%(1 \sigma)$. The data are shown in Table 1.

The trace element and rare earth compositions were determined at GSJ using an ICP-MS, followed the procedures described in (Hoang et al., 2013). The data are shown in Table 2.

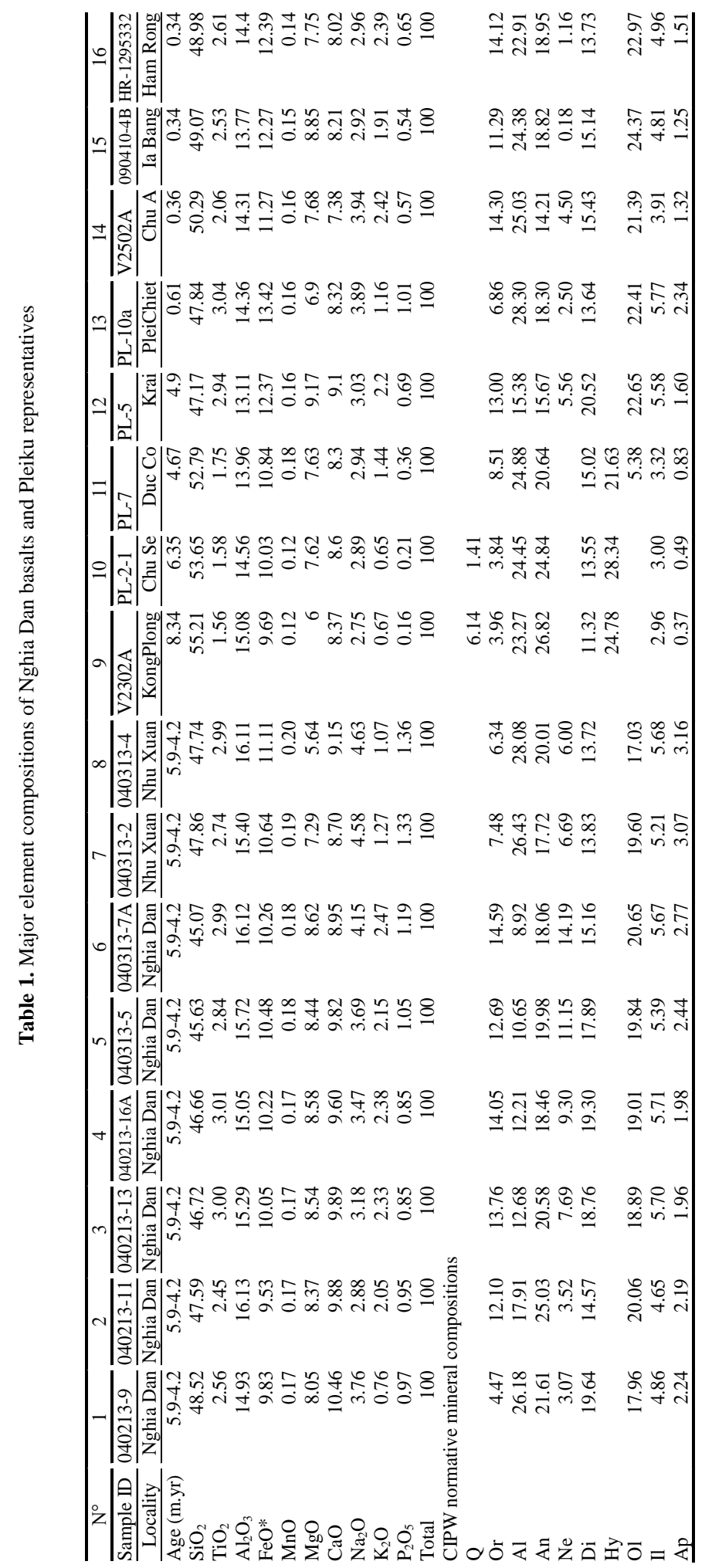


Vietnam Journal of Earth Sciences 36 (2014) 403-412

Table 2. Trace element compositions of the Nghia Dan representative basalts

\begin{tabular}{|c|c|c|c|c|c|c|c|c|}
\hline Sample ID & 040213-9 & 040213-11 & 040213-13 & 040213-16A & $040313-5$ & 040313-7A & $040313-2$ & 040313-4 \\
\hline Locality & Nghia Dan & Nghia Dan & Nghia Dan & Nghia Dan & Nghia Dan & Nghia Dan & NhuXuan & NhuXuan \\
\hline $\mathrm{Rb}(\mathrm{ppm})$ & 60.429 & 48.614 & 52.997 & 54.529 & 62.991 & 66.609 & 136.812 & 80.712 \\
\hline $\mathrm{Sr}$ & 1392.11 & 1334.579 & 1304.348 & 1432.480 & 1657.12 & 1728.425 & 1950.265 & 2033.129 \\
\hline $\mathrm{Y}$ & 28.251 & 28.572 & 28.071 & 23.883 & 31.180 & 29.253 & 34.032 & 34.930 \\
\hline $\mathrm{Zr}$ & 237.795 & 237.800 & 236.827 & 264.707 & 287.533 & 334.700 & 339.610 & 370.308 \\
\hline $\mathrm{Nb}$ & 81.876 & 84.989 & 83.451 & 86.821 & 110.792 & 121.256 & 124.784 & 138.245 \\
\hline Cs & 1.057 & 0.929 & 0.987 & 0.902 & 1.075 & 0.956 & 1.503 & 1.314 \\
\hline $\mathrm{Ba}$ & 593.983 & 639.151 & 588.208 & 607.251 & 597.480 & 640.467 & 649.062 & 718.978 \\
\hline $\mathrm{La}$ & 50.771 & 51.238 & 51.427 & 51.901 & 67.993 & 72.492 & 85.153 & 86.206 \\
\hline $\mathrm{Ce}$ & 100.740 & 99.471 & 102.636 & 109.738 & 137.842 & 143.094 & 168.466 & 173.243 \\
\hline $\operatorname{Pr}$ & 11.497 & 11.588 & 11.659 & 12.419 & 15.218 & 15.797 & 18.508 & 19.435 \\
\hline $\mathrm{Nd}$ & 48.946 & 48.660 & 48.673 & 51.319 & 63.059 & 65.386 & 74.724 & 77.250 \\
\hline $\mathrm{Sm}$ & 9.911 & 9.685 & 10.000 & 10.095 & 11.625 & 12.397 & 13.572 & 13.885 \\
\hline $\mathrm{Eu}$ & 3.167 & 3.061 & 3.179 & 3.119 & 3.478 & 3.788 & 3.988 & 4.151 \\
\hline $\mathrm{Gd}$ & 8.797 & 8.532 & 8.824 & 8.663 & 10.238 & 10.965 & 12.060 & 12.185 \\
\hline $\mathrm{Tb}$ & 1.199 & 1.198 & 1.248 & 1.138 & 1.314 & 1.357 & 1.439 & 1.581 \\
\hline Dy & 5.823 & 5.672 & 5.842 & 5.091 & 6.203 & 6.179 & 6.788 & 7.122 \\
\hline Ho & 1.061 & 1.012 & 1.048 & 0.872 & 1.116 & 1.100 & 1.229 & 1.292 \\
\hline $\mathrm{Er}$ & 2.597 & 2.521 & 2.647 & 2.146 & 2.816 & 2.695 & 3.103 & 3.185 \\
\hline $\mathrm{Tm}$ & 0.348 & 0.346 & 0.362 & 0.300 & 0.378 & 0.372 & 0.408 & 0.434 \\
\hline $\mathrm{Yb}$ & 2.167 & 2.085 & 2.153 & 1.645 & 2.311 & 2.159 & 2.542 & 2.705 \\
\hline $\mathrm{Lu}$ & 0.301 & 0.303 & 0.305 & 0.227 & 0.329 & 0.315 & 0.359 & 0.385 \\
\hline $\mathrm{Hf}$ & 5.387 & 5.372 & 5.462 & 5.896 & 6.574 & 7.394 & 7.467 & 8.100 \\
\hline $\mathrm{Ta}$ & 5.822 & 5.837 & 5.830 & 6.299 & 7.960 & 8.776 & 8.964 & 10.022 \\
\hline $\mathrm{Pb}$ & 4.036 & 4.081 & 4.198 & 4.257 & 4.532 & 4.500 & 6.878 & 8.144 \\
\hline Th & 6.706 & 6.664 & 6.709 & 6.531 & 7.996 & 8.883 & 10.128 & 11.158 \\
\hline $\mathrm{U}$ & 1.556 & 1.433 & 1.577 & 1.575 & 1.981 & 2.495 & 2.438 & 2.835 \\
\hline V & 214.242 & 206.216 & 201.508 & 229.524 & 226.218 & 195.335 & 186.100 & 232.199 \\
\hline $\mathrm{Cr}$ & 316.104 & 332.498 & 254.078 & 149.648 & 96.175 & 113.978 & 84.790 & 49.009 \\
\hline $\mathrm{Ni}$ & 164.250 & 182.594 & 156.854 & 167.475 & 128.482 & 193.502 & 105.601 & 84.360 \\
\hline
\end{tabular}

\section{Analytical results}

\subsection{Major element compositions}

Nghia Dan basalts have $\mathrm{SiO}_{2}$, varying between 45 and 48.5 wt.\% and high total alkali oxides $\left(\mathrm{Na}_{2} \mathrm{O}+\mathrm{K}_{2} \mathrm{O}\right)$, changing from 6.5 to $4.5 \mathrm{wt} . \%$. The basalts plot in fields of alkaline and highly alkaline (basanite - tephrite) (after (Cox et al., 1979) (Fig. 4a). The high alkalinity is expressed in terms of CIPW normative mineralogy where all Nghia Dan basalt samples contain nepheline $(\mathrm{Ne})$-normative from 3 to $14 \%$ (Table 1) and plot in the alkaline field (olivine-nepheline-diopside) (Fig. 4b). Note that most of 16-7 Ma DakNong volcanics, representing older Cenozoic volcanics of Central Highlands, contain quartz (Q)-normative composition; whereas younger (8-0.3 Ma) Pleiku basalts having Q-, Hy- and $\mathrm{Ne}$ - normative mineral compositions (Table1; Fig. 4b) (Hoang, 2005; Hoang and Flower, 1998; Hoang et al., 2013). The Nghia Dan basalts, forming separate distribution fields, show lower $\mathrm{SiO}_{2}$, higher $\mathrm{TiO}_{2}, \mathrm{MgO}, \mathrm{FeO} *$, $\mathrm{Al}_{2} \mathrm{O}_{3}, \mathrm{CaO}, \mathrm{Na}_{2} \mathrm{O}$ and $\mathrm{K}_{2} \mathrm{O}$ concentrations as compared to those in Pleiku and DakNong lavas (Fig. 5). In difference to the Pleiku and DakNong basalts, Nghia Dan samples do not show clear correlation between $\mathrm{Mg \#}$ and the oxides. A broad positive correlation between $\mathrm{Mg \#}$ and $\mathrm{Ni}$ (ppm) indicates fractional crystallization olivine and/or melt refreshment is an operational process in the evolution of Nghia Dan magmatism (Fig. 5) (e.g. Hirose and Kushiro, 1993). 
Nguyen Hoang et al./Vietnam Journal of Earth Sciences 36 (2014)
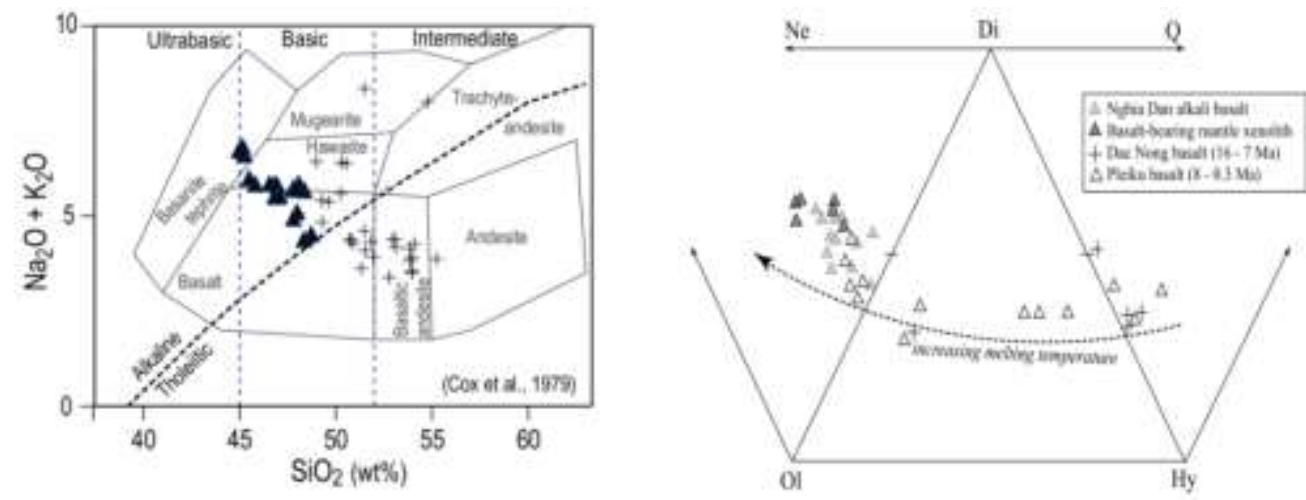

Fig. 4. a-Basaltic TAS (total akalis vs. $\mathrm{SiO}_{2}$ ) classification diagram (after Cox et al., 1979). Nghia Dan and Nhu Xuan samples (filled triangles) are plotted along with Central Highland basalts (Pleiku and DakNong: crossed) for comparison (Hoang et al., 2013); b-Basaltic classification after CIPW normative mineral constituents showing Nghia Dan samples plot in alkaline field (olivine-nepheline-diopside)
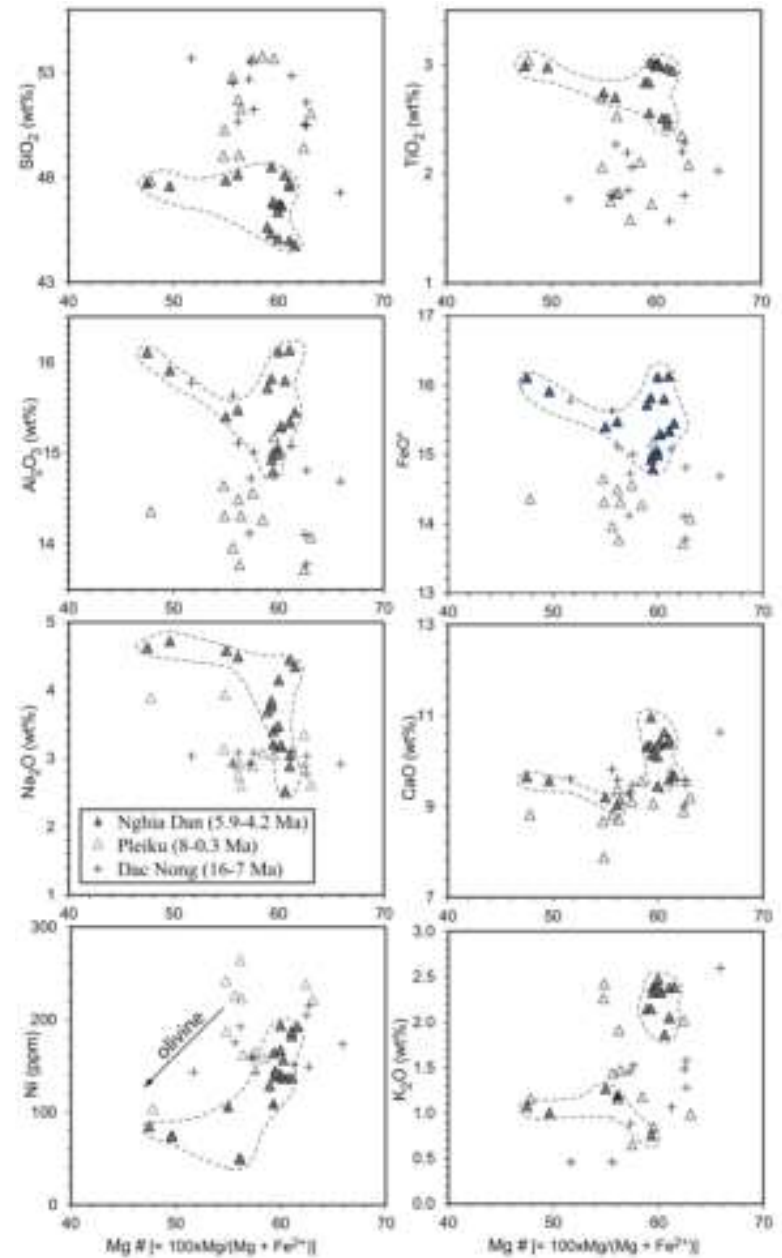

Fig. 5. Correlation between $\mathrm{Mg} \#\left[=100 \times \mathrm{Mg} /\left(\mathrm{Mg}+\mathrm{Fe}^{2+}\right)\right]$ and major silicate oxides, Ni (ppm) of Nghia Dan basalts (contoured). Pleiku and DacNong lavas from (Hoang et al., 2013) are plotted for reference

\subsection{Trace element compositions}

Primitive mantle normalized trace element (after Hofmann, 1988) and chondrite normalized rare earth (after Anders and Grevesse, 1989) distribution patterns are shown in Figure 6 along with the Pleiku and DacNong lavas for comparison (after Hoang, 2005; Hoang and Flower, 1998; Hoang et al., 2013). In general, the Nghia Dan trace element compositions decrease gradually from left to right (Fig. 6). The trace element abundances are much higher compared with those in the Pleiku olivine and alkaline basalts that have been considered as one of the most enriched Cenozoic intraplate basalts in the Highlands. The Nghia Dan rare earths are also much higher relative to the Pleiku and DacNong. The difference in absolute values (ppm) and ratios of the trace elements in Nghia Dan, Pleiku and DacNong basalts, respectively, are as follows $\mathrm{Rb}: 80,75,16$; $\mathrm{Sr}: 1700,750$, 400; Nb: 95, 60, 20; Ce/Yb: 54, 50, 20 (Tables 1 and 2). Thus, except for being relatively depleted in K, Nghia Dan alkaline basalts are highly enriched in all other elements, reflecting typical geochemistry of intraplatemagmatism (Table 2, Fig. 6). 
Vietnam Journal of Earth Sciences 36 (2014) 307-315
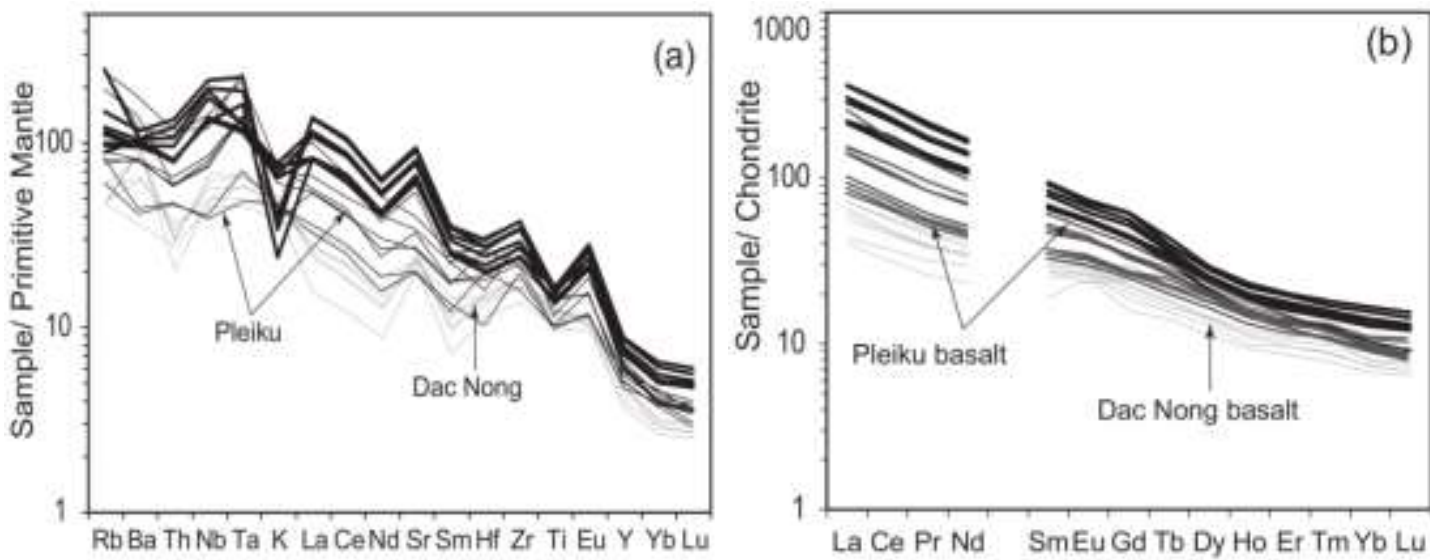

Fig. 6. Primitive mantle normalized trace element (a) (after Hofmann, 1988) and chondrite normalized rare earth element (b) (after Anders and Grevesse, 1989) configuration patterns of the Nghia Dan basalts and Highlands, for comparison. Note very high $\mathrm{Sr}, \mathrm{Eu}$, $\mathrm{Zr}$ and rare earth concentrations in Nghia Dan lavas compared with the Highland basalts

\section{Discussion}

\subsection{Crustal contamination?}

Melts on the way to the surface may interact with crustal rock. Interaction with crustal wallrock may result in increase of $\mathrm{Ba}(\mathrm{Rb}, \mathrm{Th})$ relative to $\mathrm{Nb}(\mathrm{Ta})$ in the basaltic melt to form positive correlation between ratios (such as) $\mathrm{Ba} / \mathrm{Nb}$ and $\mathrm{SiO}_{2}$ and negative correlation with $\mathrm{MgO}$ (or $\mathrm{Mg \# )}$. In difference from those observed in the Pleiku and DacNong basalts, correlation between $\mathrm{Ba} / \mathrm{Nb}$ and $\mathrm{Mg \#}$ for Nghia Dan lavas is broadly negative,

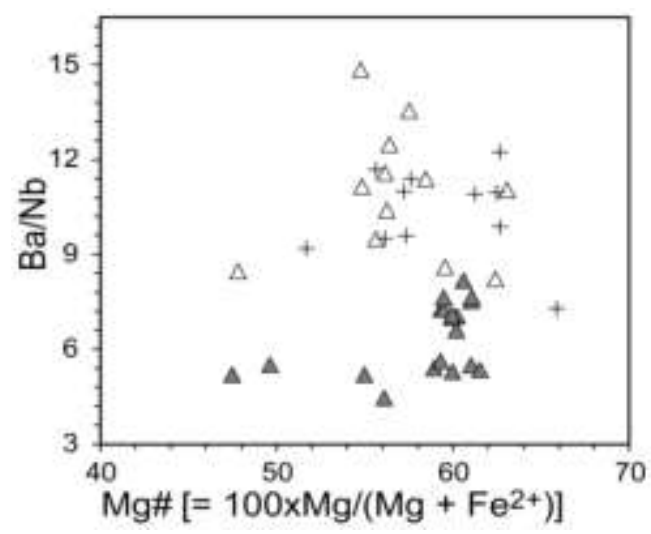

Fig.7. Plots of $\mathrm{Ba} / \mathrm{Nb}$ vs. $\mathrm{Mg} \#\left[=100 \times \mathrm{Mg} /\left(\mathrm{Mg}+\mathrm{Fe}^{2+}\right)\right]$ showing $\mathrm{Ba} / \mathrm{Nb}$ in Nghia Dan basalts almost unchanged with $\mathrm{Mg \#}$ variation. See discussion in the text suggesting, to some extent, crustal involvement and/or process of assimilation and fractional crystallization (AFC) is minimal (Fig. 7). However, the Nghia Dan and Highland Cenozoi basalts alike fall in field of mantle-derived melts, separated from a continental crust-related field by a mantle array which is determined using oceanic island basalt data (Fig. 8) (Hoang and Uto, 2003). While involvement of crustal material in the Pleiku and DacNong melts is uncertain, the Nghia Dan melts, being free from crustal wall-rock input, most certainly reflect their source geochemistry.

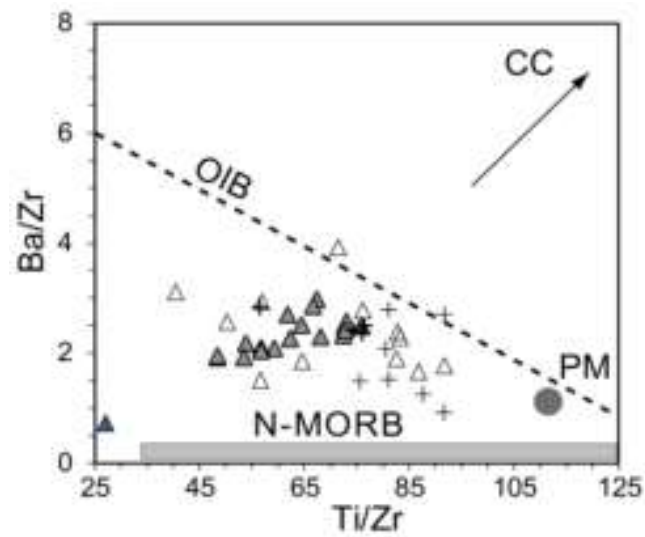

Fig. 8. Correlation between $\mathrm{Ba} / \mathrm{Zr}$ and $\mathrm{Ti} / \mathrm{Zr}$ showing Nghia Dan and Highland representative basalts in crust-free mantle source. Mantle array (dashed line) dividing fields of mantle and continental crust-influenced (CC) determined by OIB (oceanic island basalt) basalt geochemistry; PM: primitive mantle (Hofmann, 1988; Hoang and Uto, 2003); field of N-MORB (depleted Mid-Ocean Ridge basalt source) is shade 
Nguyen Hoang et al./Vietnam Journal of Earth Sciences 36 (2014)

\subsection{Mantle source and process of basaltic meltgeneration}

The trace element abundances are high in Nghia Dan basalts (Table 2). They are homogenously enriched relative to each other suggesting that they were derived from an enriched mantle source, or their melting degrees were relatively low $(<5 \%)$. Experimental petrology has demonstrated that $\mathrm{SiO}_{2}$ contents in basaltic melts are pressure-dependent; the higher pressure the lower $\mathrm{SiO}_{2}$. In contrast, $\mathrm{MgO}$ abundances are melting degree-dependent; the high melting degrees the higher $\mathrm{MgO}$ concentrations (Hirose and Kushiro, 1993; Kushiro, 1996). Experimental petrology has also shown that mixing of mantle peridotite-derived mafic melts with mafic components (such as pyroxenite) results in melts having very high $\mathrm{FeO}^{*}$ and $\mathrm{TiO} 2$ contents (Kogiso et al., 1998). In general, low $\mathrm{SiO}_{2}$ and high $\mathrm{FeO} *$, $\mathrm{TiO}_{2}, \mathrm{CaO}$ and $\mathrm{K}_{2} \mathrm{O}$ contents suggest that their being derived from a fertile (and enriched) mantle peridotite source (Turner and Hawkesworth, 1995).

Basaltic melts are being produced by partial melting of three major peridotite sources including garnet-, spinel- and plagioclase lherzolites. The stability of each of the peridotites is dependent on transitional pressures decreasing from garnet- to spinel- and plagioclase-lherzolite, respectively, from $>30 \mathrm{~Kb}(90 \mathrm{~km})$ to $30-15 \mathrm{~Kb}(90-45 \mathrm{~km})$ and $<15 \mathrm{~Kb}(<40 \mathrm{~km})$. To illustrate mantle source melting, depths and melting degrees producing Nghia Dan basaltic melts, results of petrological experiments have been served as basics for calculation. The geochemical compositions were extrapolated back to assumed primitive melts which have been described in detail in (Hoang and Flower, 1998; Hoang et al., 2013). The results were plotted in a phase diagram shown in Figure 9 (after Walker et al., 1979). The plots are distributed between 20 and $30 \mathrm{~Kb}$ sub-solidi but mostly concentrated along the $25 \mathrm{~Kb}$, equivalent to a depth of about $75 \mathrm{~km}$, in the field of spinellherzolite stability.

Mantle source, melting degree and depth may be modelled basing on the rare earth abundances. Figure 10 illustrates correlation between (chondrite-normalized) $[\mathrm{Dy} / \mathrm{Yb}]_{\mathrm{N}}$ and $[\mathrm{La} / \mathrm{Yb}]_{\mathrm{N}}$ in relation to mantle garnet- and spinel-lherzolite melting curves (after Hauri and Hart, 1994). Calculation of melting was based on assumed compositions of a given lherzolite and solid-liquid distribution coefficients (see Hauri and Hart, 1994 for details). The curves demonstrate partial melting processes in fields of garnet- and spinel lherzolite. While $[\mathrm{La} / \mathrm{Yb}]_{\mathrm{N}}$ ratios are used to illustrate melting degrees, $[\mathrm{Dy} / \mathrm{Yb}]_{\mathrm{N}}$ ratios are served as indicator of melting depth and rare earth enrichment of related source. In the melting model $[\mathrm{La} / \mathrm{Yb}]_{\mathrm{N}}$ and $[\mathrm{Dy} / \mathrm{Yb}]_{\mathrm{N}}$ ratios in Nghia Dan basaltic melts showing range of values, respectively, at 17-24 and 1.8-2.1, may be formed by melting degrees between ca. 3 and 4\% from a garnet-lherzolite source as compared with $3-5 \%$ and $5-10 \%$ for the Pleiku and DacNong melts, respectively.

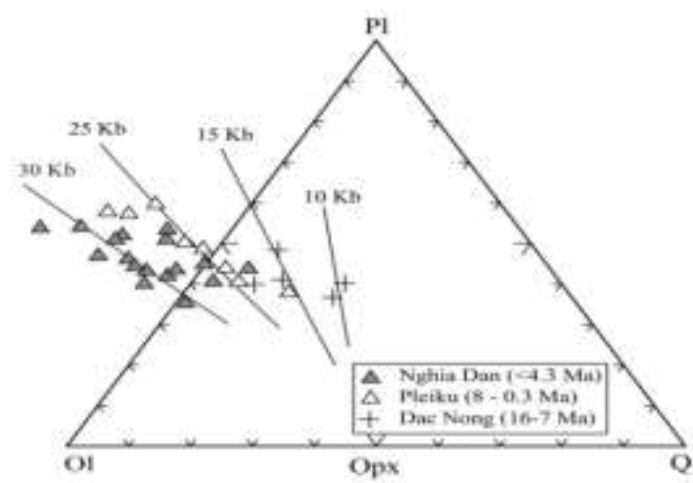

Fig. 9. Melting pressures of Nghia Dan basaltic melts relative to Highland representatives (e.g. Nguyen Hoang et al., 2013). The cotectic lines are established based on experiments by (Hirose and Kushiro, 1993; Kushiro, 1996), projection is based on (Walker et al., 1979). Method of primitive melt calculation is based on (Hoang et al., 2013)

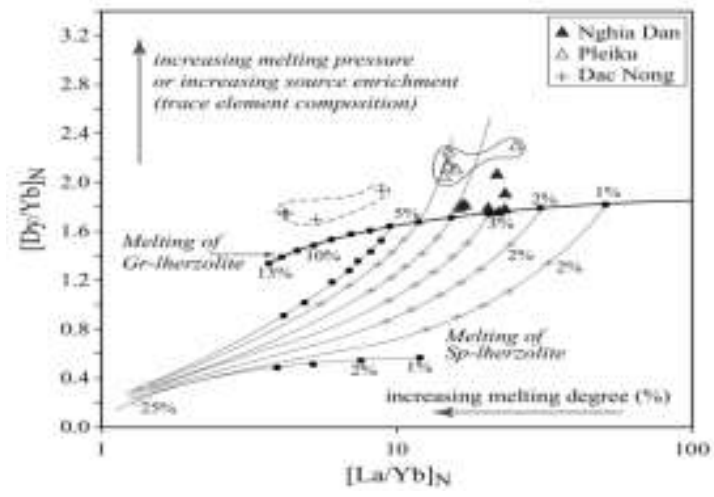

Figure 10. Source modeling and melting degree for Nghia Dan basaltic melt generation (after (Hauri and Hart, 1994; Johnson et al., 1990) as compared with Highland representative basalts. Various curves expressing melting of spinel-lherzolite at various degrees mixing with a range of garnet-lherzolitegenerated melt. Increase of chondrite normalized $\mathrm{Dy} / \mathrm{Yb}$ and $\mathrm{La} / \mathrm{Yb}$ (Anders and Grevesse, 1989) indicating, respectively, increasing melting pressure (and/or trace element enrichment) and decreasing melting degrees 
Vietnam Journal of Earth Sciences 36 (2014) 403-412

\section{Concluding remarks}

- The relatively less voluminous Nghia Dan Neogene basaltic plateau as compared to Cenozoic volcanic centers in Central Highlands of Viet Nam consists of a number of monogenetic volcanoes erupted ca. 5.9 - 4.2 Ma. Mantle xenoliths including spinel lherzolitesare discovered in alkaline basalts at several sites suggesting that the basaltic melt was generated at deep levels.

- The geochemical and petrological compositions of Nghia Dan basalts are relatively homogenous. They are alkaline basalt and basanite types, having low $\mathrm{SiO}_{2}$, and high $\mathrm{FeO}^{*}, \mathrm{TiO}_{2}$ and $\mathrm{CaO}$, suggesting that the melts were produced by melting of fertile, possibly asthenosphericperidotite at relatively high pressures. Very high $\mathrm{FeO} *(15-16.5$ wt.\%) and $\mathrm{TiO}_{2}(2.5-3.2$ wt.\%) in Nghia Dan basalts may be a result of mantle peridotite-derived melts interacting (or mixing) with mafic components in the lithospheric mantle on the way to the surface (after Hoang and Uto, 2003; Kogiso et al., 1998).

- High concentrations of highly incompatible elements such as $\mathrm{Rb}, \mathrm{Ba}, \mathrm{Th}, \mathrm{Sr}, \mathrm{Nb}$ and light rare earths in crustal contamination-free Nghia Dan basalts are most likely produced by melting of an enriched mantle source and/or by low melting degrees $(<5 \%)$. The relatively high concentrations of $\mathrm{Sr}$ and $\mathrm{Eu}$ (in primitive mantle normalized pattern) may reflect interaction of mantle-derived melts with plagioclase-rich mafic component in the lithospheric mantle.

- Melting modelling based on the major element compositions suggests that the Nghia Dan basaltic melts may be generated by melting of peridotite located between 60 and $90 \mathrm{~km}$ (ca. 20 to $30 \mathrm{~Kb}$ ) or, according to rare earth abundance-based calculation model, the melts may be produced by low melting degrees (ca. 3-4\%) of a garnet lherzolite source.

\section{Acknowledgement}

This research is funded by Viet Nam National Foundation for Science and Technology (NAFOSTED) under grant number 105.052012-22.

\section{References}

Anders, E., Grevesse, N., 1989: Abundances of the elements: meteorite and solar.GeochimicaetCosmochimicaActa 53, 197-214.

Chi, C.T., Dorobek, S.L., Richter, C., Flower, M., Kikawa, E., Nguyen, Y.T., McCabe, R., 1998: Paleomagnetism of Late Neogene basalts in Vietnam and Thailand: Implications for the Post-Miocene tectonic history of Indochina. In: Flower M.F.J., Chung, S.L., Lo, C.H., (Eds.), Mantle Dynamics and Plate Interactions in East Asia. AGU Monograph, vol. 27, Washington, D.C., pp. 289-299.

Cox, K. G., Bell, J. D. \& Pankhurst, R. J., 1979: The Interpretation of Igneous Rocks. George Allen \&Unwin.

Flower, M.F.J., Tamaki, K., Hoang, N., 1998: Mantle extrusion: a model for dispersed volcanism and DUPALlike asthenosphere in East Asia and the Western Pacific. In: M.F.J. Flower, S.L. Chung, C.H. Lo and T.Y. Lee (Editors), Mantle Dynamics and Plate Interactions inEast Asia. AGU Monograph, vol. 27, Washington, D.C., pp. 67-88.

Hauri, E. H., Hart, S. R., 1994: Constraints on melt migration from mantle plumes: A trace element study of peridotite xenoliths from Savai'i, Western Samoa. Journal of Geophysical Research 99, 24301-24321.

Hirose, K., Kushiro, I., 1993: Partial melting of dry peridotite at high pressure; determination of compositions of melts segregated from peridotite using aggregates of diamond. Earth Planetary Science Letter, 114, 477-489.

Nguyen Hoang, 2005: Lithospheric mantle beneath Pleiku: Evidence from mantle xenoliths. Geology Series A, v. 287, pp. 8-19 (in Vietnamese with English abstract)

Nguyen Hoang, Flower, M.F.J., 1998: Petrogenesis of Cenozoic basalts from Vietnam: implication for origins of a 'diffuse igneous province'. Journal of Petrology 39(3), 369-395.

Nguyen Hoang, Flower, M. F. J., Carlson, R. W., 1996: Major, trace element, and isotopic compositions of Vietnamese basalts: interaction of enriched mobile asthenosphere with the continental lithosphere.Geochimica et Cosmochimica Acta 60, 4329-4351.

Nguyen Hoang, Martin F.J. Flower, C. T. Chi, P.T. Xuan, H.V. Quy, T. T. Son, 2013: Collision-induced Basalt Eruptions at Pleiku and BuonMeThuot, South-Central Viet Nam. Journal of Geodynamics 69, 65-83.

Nguyen Hoang, Uto, K., 2003: Geochemistry of Cenozoic basalts in the Fukuoka district (northern Kyushu, Japan), 
Nguyen Hoang et al./Vietnam Journal of Earth Sciences 36 (2014)

implications for asthenosphere and lithospheric mantle interaction.Chemical Geology 198, 249-268.

Hofmann, A.W., 1988: Chemical differentiation of the Earth, the relationship between mantle, continental crust, and oceanic crust.Earth Planet. Sci. Lett. 90, 297-314.

Johnson, K.T.M., Dick, H.J.B., Shimizu, N., 1990: Melting in the oceanic upper mantle: An ion microprobe study of diopsides in abyssal peridotites. Journal of Geophysical Research 95, 2661-2678.

Kogiso, T., Hirose, K., Takahashi, E., 1998: Melting experiments on homogeneous mixtures of peridotite and basalt: application to the genesis of ocean island basalts.Earth Planet. Sci. Lett. 162, 45-61.

Kushiro, I., 1996: Partial melting of a fertile mantle peridotite at high pressure, an experimental study using aggregates of diamond.In: Basu, A., Hart, S.R. (eds.), Earth Processes, Reading the Isotopic Code. Geophys.Monogr.95, 109-122, AGU.

Lee, T-Y., Lo, C-H., Chung, S-L., Chen, C-Y., Wang, P-L., Liu, W-P., Nguyen Hoang, C.T. Chi, N.T. Yem, 1998: ${ }^{40} \mathrm{Ar} /{ }^{39} \mathrm{Ar}$ dating results of Neogene basalts in Vietnam and its tectonic implication. In: In: M.F.J. Flower, S.L. Chung, C.H. Lo and T.Y. Lee (Editors), Mantle Dynamics and Plate Interactions in East Asia, AGU Monograph, vol. 27, Washington, D.D., pp. 317-330.

Nguyen Kinh Quoc, Nguyen Thu Giao, 1980:. Cenozoic volcanic activity in Viet Nam. Geology and Mineral Resources, v. 2, 137-151 (in Vietnamese with English abstract).
Rangin, C., Huchon, P., Le Pichon, X., Bellon, H., Lepvrier, C., Roques, D., Nguyen, D.H., Phan, V.Q., 1995 : Cenozoic deformation of central and south Vietnam. Tectonophysics 251, 179-196.

Tapponnier, P., Peltzer, G., Armijo, R., 1986: On the mechanics of the collision between India and Asia. In: M.P. Coward and A.C. Ries (Editors), Collision Tectonics. Geological Society of London, special publication, pp. 115-157.

Tapponnier, P., Peltzer, G., Le Dain, A.Y., Armijo, R., Cobbold, P., 1982: Propagating extrusion tectonics in Asia: New insights from simple experiments with plasticine. Geology 7, 611-616.

Tu, K., Flower, M.F.J., Carlson, R.W., Zhang, M., Xie, G.H., 1992: Magmatism in the South China Basin, 1.Isotopic and trace element evidence for an endogenous Dupal mantle component. Chemical Geology 97, 47-63.

Turner, S., Hawkesworth, C., 1995: The nature of the subcontinental mantle: constraints from the major element composition of continental flood basalts. Chem. Geol. 120, 295-314.

Walker, D., Shibata, T., DeLong, D.E., 1979: Abyssal tholeiites from the Oceanographer Fracture Zone III. Phase equilibria and mixing. Contrib. Mineral. Petrol., 70, 111-125.

Workman, R., Hart, S.R., 2005: Major and trace element composition of the depleted MORB mantle (DMM). Earth Planet Sci. Lett., 231, 53-72.

Zindler, A., Hart, S.R., 1986: Chemical geodynamics.Annu. Rev. Earth Planet. Sci. 14, 493-571. 